Article

\title{
The Complete Mitochondrial Genome of Aleurocanthus camelliae: Insights into Gene Arrangement and Genome Organization within the Family Aleyrodidae
}

\author{
Shi-Chun Chen ${ }^{1}$, Xiao-Qing Wang ${ }^{1}$, Pin-Wu Li ${ }^{2}$, Xiang Hu ${ }^{1}$, Jin-Jun Wang ${ }^{3}$ and Ping Peng ${ }^{1, *}$ \\ 1 Tea Research Institute, Chongqing Academy of Agricultural Science, Chongqing 402160, China; \\ chensc0318@163.com (S.-C.C.); wangxiaoqing2891@126.com (X.-Q.W.); huxiang2016@126.com (X.H.) \\ 2 Tea Science Department, College of Horticulture, Sichuan Agricultural University, Ya'an 611130, China; \\ lipinwu@126.com \\ 3 Key Laboratory of Entomology and Pest Control Engineering, College of Plant Protection, \\ Southwest University, Chongqing 400715, China; wangjinjun@swu.edu.cn \\ * Correspondence: pptea2006@163.com; Tel./Fax: +86-23-4986-2028
}

Academic Editor: T. G. Emyr Davies

Received: 14 July 2016; Accepted: 1 November 2016; Published: 7 November 2016

\begin{abstract}
There are numerous gene rearrangements and transfer RNA gene absences existing in mitochondrial (mt) genomes of Aleyrodidae species. To understand how $\mathrm{mt}$ genomes evolved in the family Aleyrodidae, we have sequenced the complete mt genome of Aleurocanthus camelliae and comparatively analyzed all reported whitefly $\mathrm{mt}$ genomes. The $\mathrm{mt}$ genome of A. camelliae is $15,188 \mathrm{bp}$ long, and consists of 13 protein-coding genes, two rRNA genes, 21 tRNA genes and a putative control region (GenBank: KU761949). The tRNA gene, trnI, has not been observed in this genome. The $\mathrm{mt}$ genome has a unique gene order and shares most gene boundaries with Tetraleurodes acaciae. Nineteen of 21 tRNA genes have the conventional cloverleaf shaped secondary structure and two $\left(t r n S_{1}\right.$ and $\left.t r n S_{2}\right)$ lack the dihydrouridine (DHU) arm. Using ARWEN and homologous sequence alignment, we have identified five tRNA genes and revised the annotation for three whitefly $\mathrm{mt}$ genomes. This result suggests that most absent genes exist in the genomes and have not been identified, due to be lack of technology and inference sequence. The phylogenetic relationships among 11 whiteflies and Drosophila melanogaster were inferred by maximum likelihood and Bayesian inference methods. Aleurocanthus camelliae and T. acaciae form a sister group, and all three Bemisia tabaci and two Bemisia afer strains gather together. These results are identical to the relationships inferred from gene order. We inferred that gene rearrangement plays an important role in the mt genome evolved from whiteflies.
\end{abstract}

Keywords: Aleurocanthus camelliae; whitefly; mitochondrial genome; rearrangement; genome evolution

\section{Introduction}

Over the last decade, the mitochondrial $(\mathrm{mt})$ genome sequences have been frequently used to study species discrimination [1,2], molecule evolution [3-6], phylogenetic inferences $[3,4,7,8]$ and population genetics $[9,10]$, due to their small genome size, rapid evolutionary rate, low level or absence of sequence recombination and evolutionary conserved gene products [11,12]. With a few exceptions, animal $\mathrm{mt}$ genome is typically a circular double strand DNA molecule, with a size of 13-20 kb, consisting of a putative control region (CR) and 37 genes: 13 protein-coding genes (PCG), two ribosomal RNA genes (rRNA), and 22 transfer RNA genes (tRNA) [13-17]. The animal ancestral genome organization is retained in most insects, although minor changes were observed in some 
species [14,17]. In several groups of insects, $\mathrm{mt}$ genome organizations are not conservative and contain a lot of gene absences and rearrangements, pseudogenes or have been fragmented $[5,8,18,19]$.

In recent years, whiteflies have become an almost worldwide problem for agriculturalists. Family Aleyrodidae, with around 1450 named species, belongs to the order Hemiptera and comprise a single superfamily, Aleyrodoidea, within the suborder Sternorrhyncha [20]. Recent studies showed that $\mathrm{mt}$ genome of whiteflies have numerous gene rearrangements and transfer RNA gene absences [21-24]. Transposition of gene block cox3-trnG-nad3 and the position of $\operatorname{trn} Y$ and $\operatorname{trn} C$ are typical in whitefly $\mathrm{mt}$ genomes. The number of absent genes ranges from one to five, and the $\mathrm{mt}$ genome of Neomaskellia andropogonis has lost the most tRNAs, e.g., $\operatorname{trn} A, \operatorname{trnR}, \operatorname{trnN}, \operatorname{trnI}$ and $\operatorname{trn} S_{2}$ [21]. The gene, trnI, is missed frequently and not found in the $\mathrm{mt}$ genomes of Aleurochiton aceris, Tetraleurodes acaciae and N. andropogonis [21].

The camellia spiny whitefly, Aleurocanthus camelliae Kanmiya and Kasai (Hemiptera: Aleyrodidae), is an important pest in tea plantations and poses a risk to tea quality and production. To understand how $\mathrm{mt}$ genomes evolved in the family Aleyrodidae, the complete sequence of the $\mathrm{mt}$ genome of $A$. camelliae was sequenced and comparative analyses of all reported whitefly mt genomes were conducted.

\section{Results and Discussion}

\subsection{Genome Content and Nucleotide Composition}

The mt genome of A. camelliae (GenBank accession KU761949) is a typical closed-circular and double stranded DNA molecule. The genome contains 36 of 37 genes usually found in animal $\mathrm{mt}$ genomes, including 13 protein-coding genes (PCG), two ribosomal RNAs, 21 transfer RNAs, and a putative control region (CR) (Figure 1 and Table 1). Genes are encoded by both strands of this $\mathrm{mt}$ genome: 14 genes on one strand whereas the rest on the other strand. The camellia spiny whitefly $\mathrm{mt}$ genome is in size of $15,188 \mathrm{bp}$, which is comparable to $\mathrm{mt}$ genome of other whiteflies ranging from 14,496 bp ( $N$. andropogonis) to 18,414 bp (Trialeurodes vaporariorum) [21]. The major reason for the variation of genome size is the variable number of tandemly repeated elements in the putative control region. The control region of $A$. camelliae includes a poly-T sequence and two tandem repeat sequences, one repeat region consists of two 128 bp repeat units $(13,423-13,678)$, and the other contains eight $19 \mathrm{bp}$ repeat units $(13,737-13,888)$. Similarly, the $\mathrm{mt}$ genome of $T$. vaporariorum has five $721 \mathrm{bp}$ repeat units [21].

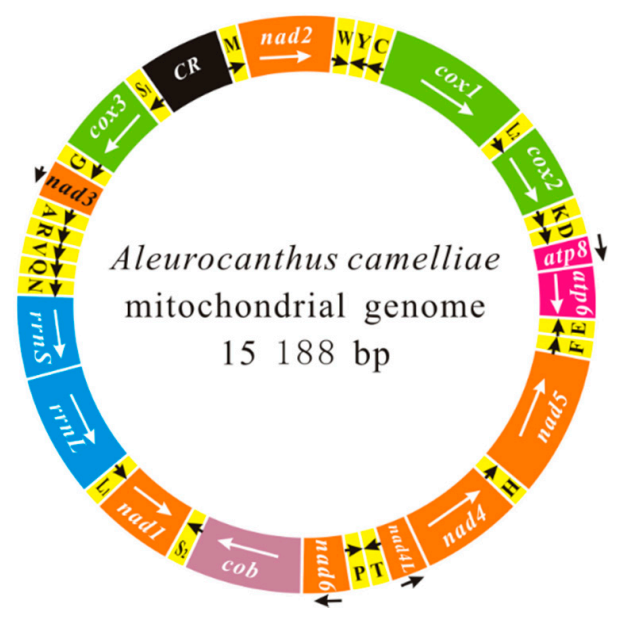

Figure 1. The mitochondrial genomes of Aleurocanthus camelliae. The transcriptional orientation is indicated with arrows. Protein-coding genes, ribosomal RNA genes and transfer RNA genes are shown in bright colors. All of them in the map follow standard abbreviations. tRNA genes for the two serine and two leucine tRNAs: $\mathrm{S}_{1}=\mathrm{AGN}, \mathrm{S}_{2}=\mathrm{UCN}, \mathrm{L}_{1}=\mathrm{CUN}$ and $\mathrm{L}_{2}=\mathrm{UUR}$. The putative control region is indicated in black. 
Table 1. Annotation and gene organization of the mitochondrial genome of Aleurocanthus camelliae.

\begin{tabular}{|c|c|c|c|c|c|c|c|c|c|}
\hline Gene $^{a}$ & Region & Size & $\operatorname{Inc}^{b}$ & $\mathrm{AT} \%$ & AT-Skew $^{c}$ & GC-Skew & $\begin{array}{l}\text { Start } \\
\text { Codon }\end{array}$ & $\begin{array}{l}\text { Stop } \\
\text { Codon }\end{array}$ & Anticodon \\
\hline $\cos 1$ & $1-1539$ & 1539 & 1 & 64.39 & -0.322 & 0.263 & ATG & TAA & - \\
\hline $\operatorname{trn} L_{2}$ & $1542-1606$ & 65 & 2 & 70.77 & -0.087 & 0.474 & - & - & TAA \\
\hline $\operatorname{cox} 2$ & $1607-2270$ & 664 & 0 & 68.67 & -0.197 & 0.202 & ATT & T- e & - \\
\hline $\operatorname{trnK}$ & $2271-2340$ & 70 & 0 & 71.43 & 0.000 & -0.100 & - & - & CTT \\
\hline $\operatorname{trn} D$ & 2347-2408 & 62 & 6 & 66.13 & -0.171 & 0.333 & - & - & GTC \\
\hline $\operatorname{atp} 8$ & 2418-2564 & 147 & 9 & 62.59 & -0.217 & 0.273 & ATA & TAA & - \\
\hline atp6 & 2558-3208 & 651 & -7 & 71.27 & -0.388 & 0.241 & ATT & TAG & - \\
\hline $\operatorname{trnE}$ & $3233-3293$ & 61 & 24 & 72.13 & 0.000 & 0.059 & - & - & TTC \\
\hline $\operatorname{trnF}$ & $3301-3363$ & 63 & 7 & 76.19 & 0.292 & 0.067 & - & - & GAA \\
\hline nad5 & $3364-5023$ & 1660 & 0 & 73.13 & 0.137 & -0.166 & ATA & T- & - \\
\hline $\operatorname{trnH}$ & 5024-5084 & 61 & 0 & 81.97 & 0.040 & 0.455 & - & - & GTG \\
\hline nad4 & $5086-6366$ & 1281 & 1 & 69.95 & -0.007 & -0.179 & ATA & TAG & - \\
\hline nad4L & $6363-6659$ & 297 & -4 & 76.77 & -0.018 & -0.246 & ATG & TAA & - \\
\hline trnT & $6661-6724$ & 64 & 1 & 76.56 & -0.102 & 0.333 & - & - & TGT \\
\hline $\operatorname{trn} P$ & $6723-6784$ & 62 & -2 & 72.58 & 0.111 & -0.059 & - & - & TGG \\
\hline nad6 & $6816-7250$ & 435 & 31 & 70.57 & -0.270 & 0.328 & ATA & TAA & - \\
\hline$c o b$ & $7250-8383$ & 1134 & -1 & 64.90 & -0.351 & 0.186 & ATG & TAA & - \\
\hline $\operatorname{trn} S_{2}$ & $8384-8439$ & 56 & 0 & 80.36 & -0.067 & 0.273 & - & - & TGA \\
\hline nad1 & $8450-9359$ & 910 & 10 & 72.86 & 0.005 & -0.198 & ATT & $\mathrm{T}-$ & - \\
\hline $\operatorname{trn} L_{1}$ & $9360-9422$ & 63 & 0 & 84.13 & 0.132 & 0.200 & - & - & TAG \\
\hline$r r n L$ & $9423-10612$ & 1190 & 0 & 77.23 & 0.134 & -0.055 & - & - & - \\
\hline$r r n S$ & 10707-11435 & 729 & 94 & 75.99 & 0.022 & 0.074 & - & - & - \\
\hline $\operatorname{trn} N$ & 11483-11548 & 66 & 47 & 78.79 & 0.115 & 0.143 & - & - & ATT \\
\hline $\operatorname{trn} Q$ & $11553-11623$ & 71 & 4 & 87.32 & 0.000 & -0.111 & - & - & TTG \\
\hline $\operatorname{trn} V$ & $11617-11680$ & 64 & -7 & 73.44 & -0.021 & 0.059 & - & - & TAC \\
\hline $\operatorname{trn} R$ & $11678-11742$ & 65 & -3 & 73.85 & -0.042 & 0.059 & - & - & TCG \\
\hline $\operatorname{trn} A$ & 11744-11805 & 62 & 1 & 75.81 & -0.021 & 0.200 & - & - & TGC \\
\hline nad3 & 11806-12159 & 354 & 0 & 72.60 & -0.276 & 0.052 & ATT & TAA & - \\
\hline $\operatorname{trn} G$ & $12161-12222$ & 63 & 1 & 82.54 & -0.038 & 0.273 & - & - & TCC \\
\hline $\cos 3$ & 12223-13009 & 786 & 0 & 66.92 & -0.198 & 0.115 & ATG & TAA & - \\
\hline $\operatorname{trn} S_{1}$ & $13025-13086$ & 62 & 15 & 61.29 & -0.263 & 0.083 & - & - & TCT \\
\hline$C R^{d}$ & 13087-13961 & 875 & 0 & 66.86 & -0.050 & 0.117 & - & - & - \\
\hline $\operatorname{trnM}$ & $13962-14028$ & 67 & 0 & 77.61 & 0.077 & -0.067 & - & - & CAT \\
\hline nad2 & 14029-15003 & 975 & 0 & 68.72 & -0.287 & 0.279 & ATA & TAA & - \\
\hline $\operatorname{trnW}$ & $15002-15064$ & 63 & -2 & 82.54 & 0.077 & 0.091 & - & - & TCA \\
\hline $\operatorname{trn} Y$ & 15063-15124 & 60 & -2 & 86.67 & 0.154 & 0.500 & - & - & GTA \\
\hline $\operatorname{trn} C$ & 15125-15187 & 63 & 0 & 92.06 & 0.138 & 0.200 & - & - & GCA \\
\hline
\end{tabular}

A total of $28 \mathrm{bp}$ overlaps have been found at eight gene junctions of this $\mathrm{mt}$ genome, and the size of overlaps are ranging from 1 to $7 \mathrm{bp}$. Except for the putative control region, the genome has a total of $254 \mathrm{bp}$ of intergenic sequence at 16 locations ranging from 1 to $94 \mathrm{bp}$, and the longest intergenic sequence is located between $r r n L$ and $r r n S$. Unlike A. camelliae, a $53 \mathrm{bp}$ long intergenic sequence locates between $r r n L$ and $t r n V$ in the $\mathrm{mt}$ genome of T. acaciae [21].

As for all other insects, the nucleotide composition of the $\mathrm{mt}$ genome of A. camelliae is biased toward A and T nucleotides, with an A + T content of $70.90 \%$. It consists of $69.49 \%$ in the protein coding genes, $76.61 \%$ in the ribosomal RNA genes, $77.19 \%$ in the transfer RNA genes and $66.86 \%$ in the putative control region, respectively (Table 2). Excluding the incomplete stop codons, a total of 3610 amino acids of protein-coding genes are encoded in the camellia spiny whitefly mt genome. The high $\mathrm{A}+\mathrm{T}$ content is reflected in the codon usage, especially in the third position: codons for $\mathrm{A}$ or $\mathrm{T}(\mathrm{A}=33.88 \%, \mathrm{~T}=40.46 \%)$ are strongly preferred over $\mathrm{C}$ or $\mathrm{G}(\mathrm{C}=14.19 \%, \mathrm{G}=11.47 \%)$ in the third codon position. The most frequent amino acids in the PCGs of the camellia spiny whitefly are Leucine $(13.95 \%)$, Serine $(10.37 \%)$, Phenylalanine $(9.69 \%)$ and Isoleucine $(9.36 \%)$ (Table 3$)$. 
Table 2. Nucleotide composition of the mitochondrial genome of Aleurocanthus camelliae.

\begin{tabular}{cccccccc}
\hline Region & $\mathbf{A} \%$ & $\mathbf{C} \%$ & $\mathbf{G} \%$ & $\mathbf{T} \%$ & $\mathbf{A T} \%$ & AT-Skew & GC-Skew \\
\hline Full length & 31.02 & 12.38 & 16.72 & 39.87 & 70.90 & -0.125 & 0.149 \\
PCGs & 29.27 & 14.12 & 16.64 & 39.96 & 69.49 & -0.154 & 0.082 \\
1st codon & 35.12 & 13.20 & 20.62 & 31.05 & 66.37 & 0.061 & 0.219 \\
2nd codon & 18.81 & 17.70 & 15.12 & 48.37 & 68.08 & -0.440 & -0.078 \\
3rd codon & 33.88 & 11.47 & 14.18 & 40.47 & 74.02 & -0.089 & 0.106 \\
tRNA genes & 39.51 & 9.75 & 13.04 & 37.71 & 77.19 & 0.023 & 0.145 \\
rRNA genes & 41.90 & 11.67 & 11.57 & 34.86 & 76.61 & 0.092 & -0.004 \\
\hline
\end{tabular}

Table 3. Codon usage for the 13 mitochondrial protein-coding genes of Aleurocanthus camelliae.

\begin{tabular}{cccccccccccc}
\hline Codon & $\mathbf{N}$ & $\%$ & RSCU & Codon & $\mathbf{~ N}$ & $\%$ & RSCU & Codon & N & $\%$ & RSCU \\
\hline UAA (*) & 8 & 0.22 & 1.60 & AAA (K) & 79 & 2.19 & 1.30 & AGA (S) & 76 & 2.11 & 1.63 \\
UAG (*) & 2 & 0.06 & 0.40 & AAG (K) & 43 & 1.19 & 0.71 & AGC (S) & 23 & 0.64 & 0.49 \\
GCA (A) & 62 & 1.72 & 1.56 & CUA (L) & 91 & 2.52 & 1.54 & AGG (S) & 22 & 0.61 & 0.47 \\
GCC (A) & 23 & 0.64 & 0.58 & CUC (L) & 16 & 0.44 & 0.27 & AGU (S) & 55 & 1.52 & 1.18 \\
GCG (A) & 14 & 0.39 & 0.35 & CUG (L) & 42 & 1.16 & 0.71 & UCA (S) & 83 & 2.30 & 1.78 \\
GCU (A) & 60 & 1.66 & 1.51 & CUU (L) & 87 & 2.41 & 1.48 & UCC (S) & 18 & 0.50 & 0.39 \\
UGC (C) & 17 & 0.47 & 0.74 & UUA (L) & 178 & 4.93 & 1.33 & UCG (S) & 17 & 0.47 & 0.36 \\
UGU (C) & 29 & 0.80 & 1.26 & UUG (L) & 90 & 2.49 & 0.67 & UCU (S) & 80 & 2.22 & 1.71 \\
GAC (D) & 22 & 0.61 & 0.70 & AUA (M) & 225 & 6.23 & 1.54 & ACA (T) & 76 & 2.11 & 1.62 \\
GAU (D) & 41 & 1.14 & 1.30 & AUG (M) & 67 & 1.86 & 0.46 & ACC (T) & 19 & 0.53 & 0.40 \\
GAA (E) & 57 & 1.58 & 1.37 & AAC (N) & 48 & 1.33 & 0.63 & ACG (T) & 6 & 0.17 & 0.13 \\
GAG (E) & 26 & 0.72 & 0.63 & AAU (N) & 104 & 2.88 & 1.37 & ACU (T) & 87 & 2.41 & 1.85 \\
UUC (F) & 46 & 1.27 & 0.26 & CCA (P) & 26 & 0.72 & 1.11 & GUA (V) & 85 & 2.35 & 1.30 \\
UUU (F) & 304 & 8.42 & 1.74 & CCC (P) & 18 & 0.50 & 0.77 & GUC (V) & 21 & 0.58 & 0.32 \\
GGA (G) & 62 & 1.72 & 1.39 & CCG (P) & 13 & 0.36 & 0.55 & GUG (V) & 49 & 1.36 & 0.75 \\
GGC (G) & 20 & 0.55 & 0.45 & CCU (P) & 37 & 1.02 & 1.57 & GUU (V) & 106 & 2.94 & 1.63 \\
GGG (G) & 55 & 1.52 & 1.23 & CAA (Q) & 29 & 0.80 & 1.14 & UGA (W) & 68 & 1.88 & 1.36 \\
GGU (G) & 42 & 1.16 & 0.94 & CAG (Q) & 22 & 0.61 & 0.86 & UGG (W) & 32 & 0.89 & 0.64 \\
CAC (H) & 22 & 0.61 & 0.86 & CGA (R) & 18 & 0.50 & 1.60 & UAC (Y) & 48 & 1.33 & 0.65 \\
CAU (H) & 29 & 0.80 & 1.14 & CGC (R) & 5 & 0.14 & 0.44 & UAU (Y) & 99 & 2.74 & 1.35 \\
AUC (I) & 48 & 1.33 & 0.28 & CGG (R) & 12 & 0.33 & 1.07 & - & - & - & - \\
AUU (I) & 291 & 8.06 & 1.72 & CGU (R) & 10 & 0.28 & 0.89 & - & - & - & - \\
\hline
\end{tabular}

* represents stop codon.

The total length of all 13 protein-coding genes is $10,833 \mathrm{bp}$, which accounts for $71.33 \%$ of the whole length of the mt genome of A. camelliae. All PCGs initiate translation using an ATN codon (ATA for atp8, nad2 and nad4-6; ATT for atp6, cox2, nad1 and nad3; ATG for cob, cox1, cox3 and nad4L). Three PCGs (cox2, nad1 and nad5) have incomplete terminal codons consisting of "T-" nucleotide, and other stop with TAA and TAG (Table 1). Incomplete stop codons are common in animal mt genomes and could produce functional stop codons in polycistronic transcription cleavage and polyadenylation mechanisms $[25,26]$.

All 22 tRNA genes usually found in the $\mathrm{mt}$ genomes of insects are present in A. camelliae, except for trnI. Seven of the 21 tRNA genes are encoded by one strand and the remaining genes are encoded by the other strand. The nucleotide length of tRNA genes are ranging from $56 \mathrm{bp}\left(\operatorname{trnS}_{2}\right)$ to $71 \mathrm{bp}$ $(\operatorname{trn} Q)$, and $\mathrm{A}+\mathrm{T}$ content are ranging from $61.29 \%\left(\operatorname{trn} S_{1}\right)$ to $92.06 \%(\operatorname{trn} C)$ (Table 1$)$. In the mt genome of A. camelliae, 19 of 21 tRNA genes have the conventional cloverleaf shaped secondary structure and two $\left(t r n S_{1}\right.$ and $\left.t r n S_{2}\right)$ lacks the dihydrouridine (DHU) arm (Figure 2). The gene $t r n S_{1}$ almost lacks the DHU arm in all metazoans $[3,4,6]$, and $t r n S_{2}$ without DHU arm also exists in B. tabaci Asia I [27] and N. andropogonis (Figure 2). In the 21 tRNA genes of A. camelliae, 39 unmatched base pairs were found, and they can be corrected through RNA-editing mechanisms that are well known for insect mtDNA [28]. 

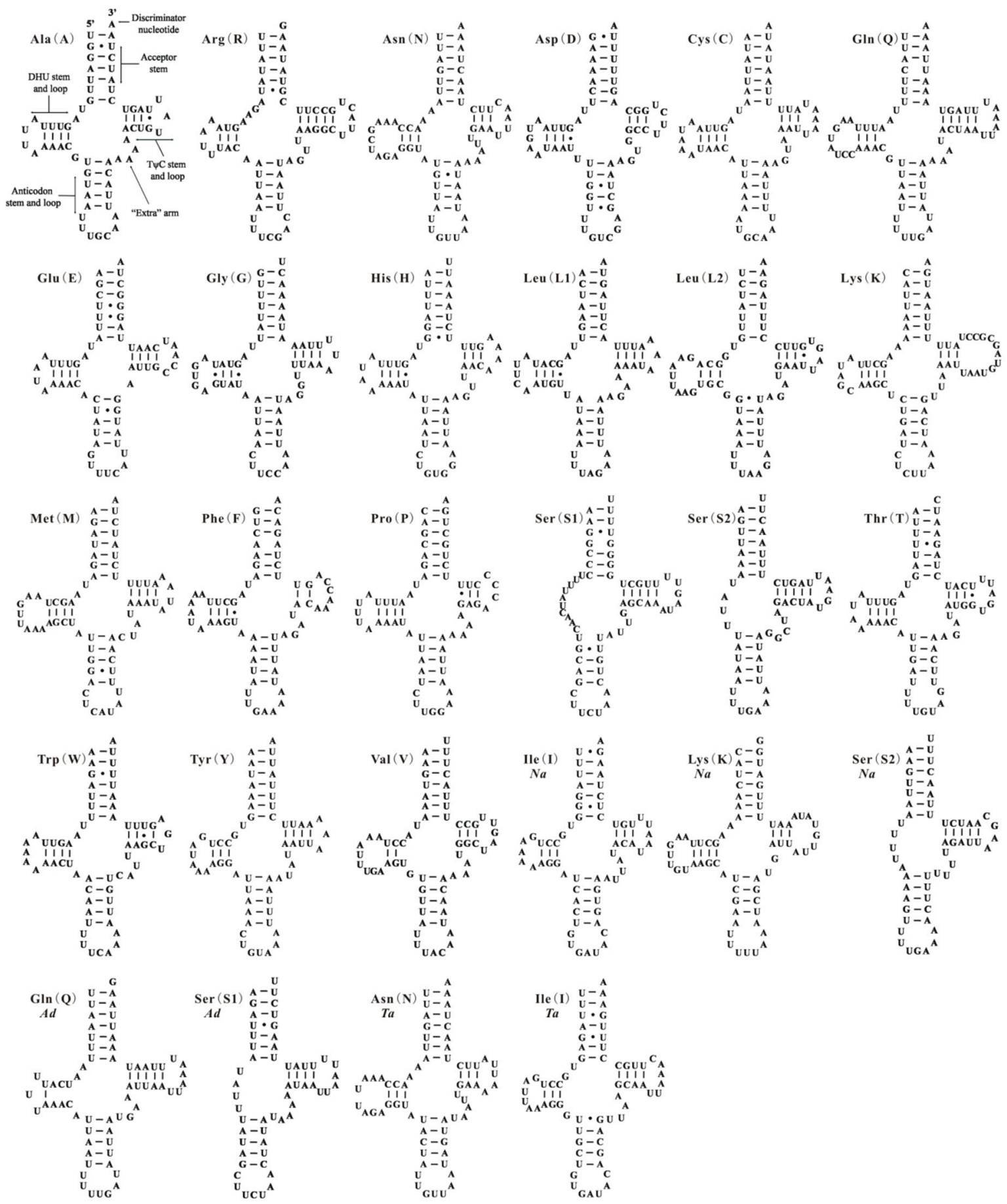

Figure 2. Putative secondary structures of the tRNA genes identified in this study. Bars indicate Watson-Crick base pairings, and dots between $G$ and $U$ pairs mark canonical base pairings appearing in RNA. Seven tRNA genes identified in this study of the mitochondrial genomes of Aleurodicus dugesii $(\mathrm{Ad})$, Neomaskellia andropogonis $(\mathrm{Na})$ and Tetraleurodes acaciae ( $\mathrm{Ta}$ ) with species name abbreviation below gene name.

\subsection{Re-Annotation for Whitefly Mitochondrial Genomes}

In the camellia whitefly $\mathrm{mt}$ genome, we identified 36 of 37 genes usually found in animal $\mathrm{mt}$ genomes, and gene trnI was not found. Gene absence is common in reported Aleyrodidae mt genomes, e.g., A. aceris without trnI, Aleurodicus dugesii without $\operatorname{trn} S_{1}$ and $\operatorname{trn} Q$, T. acaciae without $\operatorname{trnI}, \operatorname{trn} S_{1}$ and 
$\operatorname{trn} N$, and $N$. andropogonis without $\operatorname{trn} A, \operatorname{trnR}, \operatorname{trn} N, \operatorname{trnI}$ and $\operatorname{trn} S_{2}$ [21]. The event of a gene disappearing has also occurred in mt genome of other animals, such as booklice $[8,19]$ and arrow worm [29]. In some extreme cases, Cnidaria and Chaetognatha species lose nearly all their transfer RNA genes $[29,30]$. Current studies suggest that there are three reasons for gene absence of animal mt genomes. The first, the missing genes have been deleted and functionally replaced by nuclear tRNAs [31]. The second, the $\mathrm{mt}$ genome is fragmented and the missing genes are encoded by another unsequenced chromosome, like booklice [8,19], human lice [6], rotifer [32,33] and yellow tea thrips [18]. Thirdly, the disappeared genes actually exist in the circular DNA molecule, but have not been identified due to their rapid evolutionary rates. For example, earlier study indicated that the nad 3 gene was lost from the $\mathrm{mt}$ genome of Metaseiulus occidentalis [34], and the gene had been identified in a subsequent report [35].

In this study, we have constructed tRNA secondary structure using ARWEN additionally and aligned homologous gene sequences from other whiteflies. Five tRNA genes have been identified firstly in three whiteflies: $\operatorname{trnS}_{1}$ and $\operatorname{trn} Q$ for A. dugesii, $\operatorname{trnI}$ and $\operatorname{trnN}$ for T. acaciae and $\operatorname{trnI}$ for $N$. andropogonis (Figures 2 and 3, Table S1). For the $\mathrm{mt}$ genome of $N$. andropogonis, $\operatorname{trnK}$ and $\operatorname{trnS}_{2}$ have been re-annotated and cox 2 gene has been reduced to $661 \mathrm{bp}$ by tRNA punctuation model of trnK [36]. In original annotation, cox2 gene $(717 \mathrm{bp})$ is much longer than those of other Aleyrodidae species (661-667 bp), and $\operatorname{trnK}$ takes up the usual position of $\operatorname{trn} S_{2}$ : thus, $\operatorname{trn} S_{2}$ (14428-14493) huddles together with $\operatorname{trn} W$ (14430-14493). Gene trnQ of two whiteflies, A. camelliae and A. dugesii, have almost identical anticodon stem and loops, acceptor stems and T $\psi C$ stem and loops. However, trn $Q$ of $A$. dugesii nearly lost the DHU arm. The gene sequence has been much changed in the process of evolution, which increases the difficulty of gene identification. It infers that most gene absences of Aleyrodidae $\mathrm{mt}$ genome belong to the third situation of those mentioned above.

\subsection{Gene Arrangement}

The $\mathrm{mt}$ gene arrangement in A. camelliae is unique and different from that of the ancestral insect and other whiteflies (Figure 3). Mt gene rearrangement is also a common phenomenon for all Aleyrodidae species. As for most whiteflies, A. camelliae has the specific inverse transposition of gene block cox3-trnG-nad3 and the position of $\operatorname{trn} Y$ and $\operatorname{trn} C$ [21]. The gene order of camellia spiny whitefly is similar to that of T. acaciae. The two gene blocks, atp8-atp6-trnE-trnF-nad5-trnH-nad4-nad4L-trnTtrnP-nad6-cob-trnS ${ }_{2}$-nad1-trnL $L_{1}-r r n L-r r n S$ and $\operatorname{trn} Q-\operatorname{trn} V$, only exist in the $\mathrm{mt}$ genomes of A. camelliae and T. acaciae. For the two whiteflies, gene $r r n S$ is immediately followed by $r r n L$, with no transfer RNA gene but a long non coding sequence ( 94 and $53 \mathrm{bp}$ ) between them. However, the other whiteflies have one or more transfer genes between the two rRNAs [21-24,27].

There are numerous gene rearrangements have apparently occurred in the whitefly mt genomes, and the gene order map gives evidences to understand the process of rearrangements. For the major rearrangement, cox3-trnG-nad3-trnA-trnR-trnN firstly inverse transposed as a unit [21], subsequently, $\operatorname{trn} A, \operatorname{trnR}$ and $\operatorname{trnN}$ have undergone transpositions independently. In Figure 3, B. tabaci and B. afer contain the whole inverse unit, A. camelliae and A. aceris with inverse cox3-trnG-nad3-trnA-trnR, and T. acaciae and N. andropogonis just have inverse cox3-trnG-nad3. Additionally, tRNA cluster $t_{r n S_{1}-t r n E-t r n F}$ has been left in the $\mathrm{mt}$ genomes of B. tabaci, B. afer, A. aceris and N. andropogonis. With cox3-trnG-nad3-trnA-trnR-trnN rearranged, the two ends of the unit became "hot spots" of tRNA gene transposition and insertion. For the $\mathrm{mt}$ genome of $A$. camellia, $\operatorname{trn} Q-\operatorname{trn} V$ could be inserted after cox3-trnG-nad3-trnA-trnR-trnN rearranged, while six genes of the rearrangement unit maintain the original relative position. For T. acaciae, A. aceris and N. andropogonis, one or more tRNAs inserted into "hot spots" and $\operatorname{trn} N$ or all the three tRNAs $(\operatorname{trn} A, \operatorname{trnR}$ and $\operatorname{trn} N)$ moved away. Thus, $\operatorname{trn} A$, $\operatorname{trn} R$ and $\operatorname{trn} N$ in $N$. andropogonis have probably been rearranged several times and the sequences have been changed a lot. Once the tRNA genes lost their anticodons and functions, they would be eliminated. Rearrangement steps of $t r n S_{1}-\operatorname{trn} E-t r n F$ are much clearer. The first step is the inversion of $\operatorname{trnS}_{1}$ (A. aceris and N. andropogonis), the second is inversion of $\operatorname{trnE}$ (B. tabaci and B. afer) and the last is the transposition of $\operatorname{trn} S_{1}$ (A. camelliae and T. acaciae). These rearrangement steps could be used to gain information of phylogenies. 
To understand the mechanism that causes whitefly mt genome rearrangement, we conduct a comparative analysis among all Aleyrodidae mt genomes. Gene block trnT-trnP is common in all whitefly $\mathrm{mt}$ genomes, and a $71 \mathrm{bp}$ non-coding region replaces $\operatorname{trn} P$ between $\operatorname{trnT}$ and nad 6 in $N$. andropogonis (Table S1). The $\mathrm{mt}$ genomes of A. camelliae and T. acaciae have the same situation, and a non-coding region instead of $\operatorname{trn} V$ locates between the two rRNA genes. These observations are highly consistent with the tandem duplication/random loss (TDRL) model, which is the widely accepted mechanism for local gene rearrangements in animal $\mathrm{mt}$ genomes [37]. However, most of genome rearrangements in Aleyrodidae are consistent with the intramolecular recombination mechanism, because gene inversions cannot be explained without some form of recombination [38-40]. The control region (CR) has been considered as a "hot spot" of recombination [41]. For whiteflies, gene block cox3-trnG-nad3 usually translocates close to the control region. Besides cox3-trnG-nad3, many rearrangements with inversions occurred around CR, such as $r r n S-t r n V$ of $N$. andropogonis, $\operatorname{trn} A$ and $\operatorname{trn} D$ of T. acaciae, and $\operatorname{trn} Q$ of $A$. dugesii. The results indicate that both TDRL model and intramolecular recombination participate in genome rearrangement of whiteflies, and the latter plays a more important role.

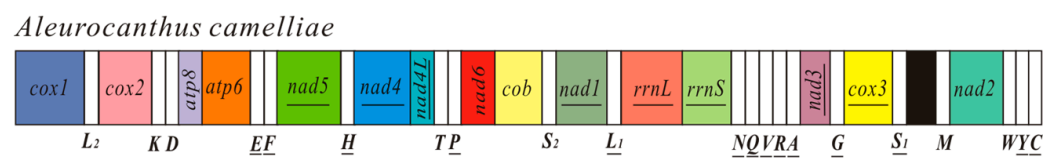

Tetraleurodes acaciae

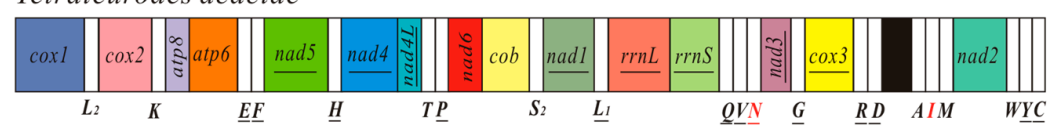

Bemisia tabaci and B. afer

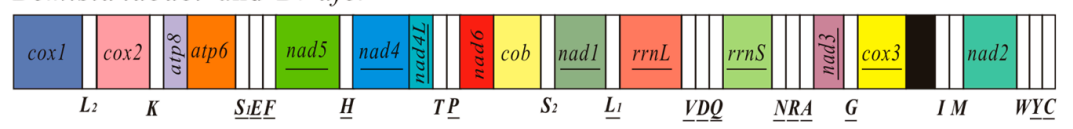

Aleurochiton aceris

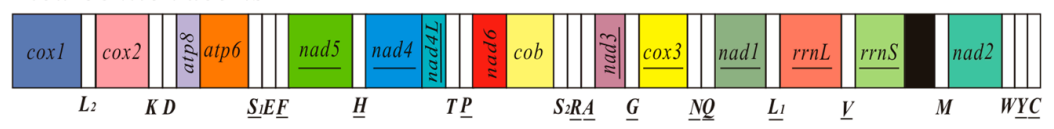

Neomaskellia andropogonis
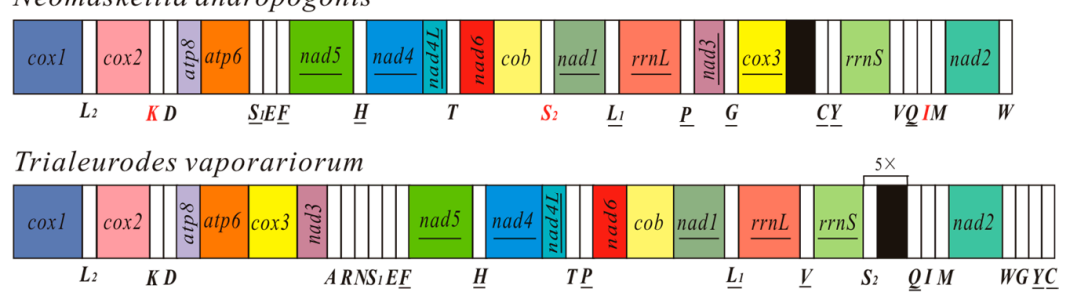

Aleurodicus dugesii

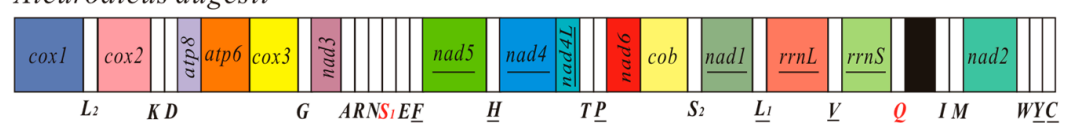

Ancestral insect

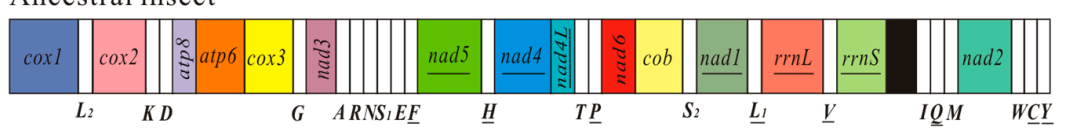

Figure 3. Arrangement of mitochondrial genes in the family Aleyrodidae and the hypothetical ancestral insect. Circular genomes have been arbitrarily linearized for ease of comparison. Gene names are the standard abbreviations used in the present study. Transfer RNA genes are designated by the single-letter amino acid codes, and red letters represent the tRNAs identified in this study. Genes which are underlined are encoded on the different strand from that of cox 1 . White boxes represent transfer RNA genes and bright colors represent 13 protein-coding genes and 2 ribosomal RNA genes. 


\subsection{Phylogenetic Analyses}

Two methods, maximum likelihood (ML) and Bayesian inference (BI), were used to determine phylogenetic relationships among 11 whiteflies from the family Aleyrodidae, with nucleotide and deducted amino acid sequences of $\mathrm{mt}$ genomes (Figure 4). Phylogenetic relationships among 11 whiteflies and D. melanogaster based on $\mathrm{mt}$ genome sequence are concordant with that inferred from $\mathrm{mt}$ gene order. A. camelliae and T. acaciae share most gene boundaries to each other and they are clustered into a branch of the phylogenetic tree with strong support $(100 \%$ bootstrap value and 1.0 posterior probabilities). Similarly, three $B$. tabaci and two B. afer strains gather together and they have the same mitochondrial gene arrangement. In the cluster $A$, all species contain the insertion position of cox3-trnG-nad3 and differ in tRNAs, that it is possible tRNA rearrangements followed the insertion of the transposed fragment in a common ancestor [21]. Based on rearrangement steps of $t r n S_{1}$-trnE-trnF, A. aceris and N. andropogonis split out firstly with the $t r n S_{1}$ inversion, B. tabaci and B. afer followed them with trnE inversion. The gene order of the $\mathrm{mt}$ genome of A. dugesii and T. vaporariorum nearly have the ancestral gene composition and arrangement and contain a few tRNA rearrangements. Meanwhile, these two whiteflies locate more closely than the others to D. melanogaster in the phylogenetic tree, which insect has the same mt gene order as the ancestral insect [3,42]. It can be inferred that gene rearrangement plays an important role in the $\mathrm{mt}$ genome evolution in the family Aleyrodidae, and confirmed that the rearrangements are reliable phylogenetic markers $[3,7,43]$.

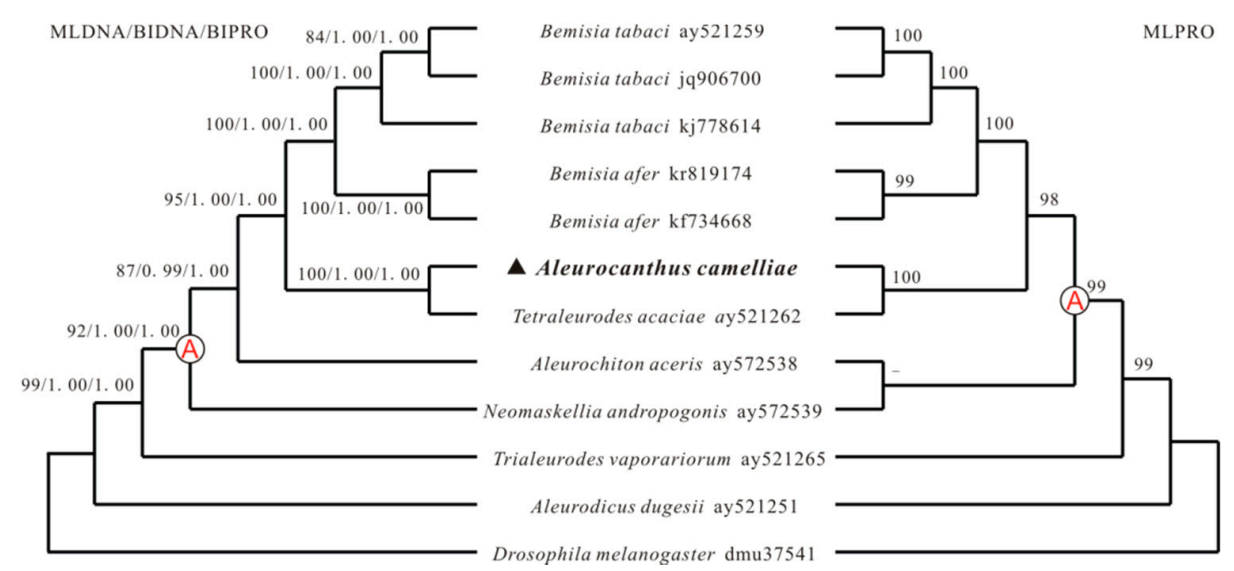

Figure 4. Phylogeny from Aleyrodidae mitochondrial genome sequences. Numbers above the branches show maximum likelihood (ML) bootstrap support values and Bayesian (BI) posterior probabilities for the phylogenies. Only support above $50 \%$ is shown. All mitochondrial genomes of clade A contain the rearrangement of cox3-trnG-nad3.

\section{Materials and Methods}

\subsection{Ethics Statement and Sample Collection}

The camellia spiny whiteflies were collected at tea plantation in Yongchuan, Chongqing, China in 16 March 2015, and identified to species by morphology [2] and sequence of cox1 [2,44] in 30 March 2015. Voucher specimens (\#CQNKY-HE-02-01-01) were deposited at the Insect Collection, Tea Research Institute of Chongqing Academy of Agricultural Science, Chongqing, China. The sampling tea plantation belongs to Chongqing Academy of Agricultural Science, and the whitefly is a tea pest and not a protected species.

\subsection{DNA Extraction and mt Genome Amplification}

Total genomic DNA was extracted using a Dneasy Blood and Tissue Kit (Qiagen, Hilden, Germany) and stored at $-20^{\circ} \mathrm{C}$. Referenced gene order of other whiteflies, the $\mathrm{mt}$ genome of $A$. camelliae were amplified in seven overlapping fragments by long-PCR with conserved insect primers $[12,45,46]$ and 
specific primers designed in this study (Table 4). All fragments were sequenced and assembled into a contig with SeqMan (DNAStar).

Table 4. PCR primers for amplification of the mitochondrial genome of Aleurocanthus camelliae.

\begin{tabular}{cccc}
\hline Region & Primer Name & Primer Sequence (5'-3') & References \\
\hline \multirow{2}{*}{ cox1-nad5 } & C1-J-2195 & TTGATTTTTGGTCATCCAGAAGT & {$[45]$} \\
& N5-N7793 & TTAGGTTGRGATGGNYTAGG & {$[12]$} \\
\hline \multirow{2}{*}{$n a d 5-c o b$} & AC-N5J & CAGCAGTTACTAGAGTTGATGAGT & In this study \\
& AC-CBN & TCTCCACAAACAATAAAACAAGC & In this study \\
\hline \multirow{2}{*}{ cob-rrnL } & CBF1 & TATGTACTACCATGAGGACAAATATC & {$[46]$} \\
& AC-16SN & GTCTAAGTCTTAAATAAACTCTGC & In this study \\
\hline \multirow{2}{*}{$r r n L$} & 16Sar & CGCCTGTTTAACAAAAACAT & {$[46]$} \\
& 16Sbr & CCGGTCTGAACTCAGATCACGT & {$[46]$} \\
\hline \multirow{2}{*}{$r n L-r r n S$} & AC-16SJ & TTAGAGGAACCTGCTTAGTAATC & In this study \\
& AC-12SN & GCAGAGTTTATTTAAGACTTAGAC & In this study \\
\hline \multirow{2}{*}{$r m S$} & 12SRNA-F & AAACTAGGATTAGATACCCTATTAT & {$[46]$} \\
& 12SRNA-R & AAGAGCGACGGGCGATGTGT & {$[46]$} \\
\hline \multirow{2}{*}{$r n S-\operatorname{cox} 1$} & AC-12SJ & CCCTGATACAAAAGGTACAAGTCT & In this study \\
& AC-C1N & CCCATAATAGCAAATACAATCCCT & In this study \\
\hline
\end{tabular}

Each long-PCR reaction is $25 \mu \mathrm{L}$ in total volume, containing $1.0 \mu \mathrm{L}$ each of forward primer $(10 \mu \mathrm{M})$ and reverse primer $(10 \mu \mathrm{M}), 4.0 \mu \mathrm{L}$ of dNTPs mix (each $2.5 \mathrm{mM}$ ), $1.0 \mu \mathrm{L}$ of template DNA, $2.5 \mu \mathrm{L}$ $\mathrm{MgCl}_{2}(25 \mathrm{mM}), 2.5 \mu \mathrm{L}$ of $10 \times \mathrm{LA}$ PCR reaction buffer II, $12.75 \mu \mathrm{L} \mathrm{ddH}_{2} \mathrm{O}$ and $0.25 \mu \mathrm{L}$ LA Taq DNA polymerase $\left(5 \mathrm{U} / \mu \mathrm{L}\right.$, Takara, Dalian, China). All reactions were carried out using $\mathrm{C} 1000^{\mathrm{TM}}$ thermal cyclers (Bio-RAD, Hercules, CA, USA) with the following conditions: 2 min denaturation at $94{ }^{\circ} \mathrm{C}$, 35 cycles of $94^{\circ} \mathrm{C}$ for $30 \mathrm{~s}, 55^{\circ} \mathrm{C}$ for $30 \mathrm{~s}, 68^{\circ} \mathrm{C}$ for $1-5 \mathrm{~min}$ (depending on target size, $\sim 1 \mathrm{~min} / \mathrm{kb}$ ), followed by a final extension at $68^{\circ} \mathrm{C}$ for $10 \mathrm{~min}$. PCR products were directly sequenced with both forward and reverse PCR primers and internal primers by primer walking. All products in this study were sequenced by Life Technologies in Guangzhou, China.

\subsection{Sequence Annotation and Analysis}

The protein-coding genes were firstly identified by the ORF Finder (available online: http:/ / www.ncbi.nlm.nih.gov/gorf/gorf.html) and rRNA genes by BLAST searches, then confirmed by alignment with homologous genes from other species of Aleyrodidae (Table 5). The transfer RNA genes were identified by cloverleaf secondary structure using ARWEN [47] with default parameters and tRNAscan-SE 1.21 [48] with the parameters: Search Mode = "EufindtRNA-Cove", Genetic Code = "Invertebrate Mito" and Cove score cutoff $=1$. The base composition was analyzed with BioEdit 7.2.5 (http:/ / www.softpedia.com/get/Science-CAD/BioEdit.shtml). Sequences of mt genomes of other whiteflies were retrieved from GenBank (Table 5).

Table 5. GenBank accession numbers and mitochondrial genome sizes of the species included in phylogenetic analysis in this study.

\begin{tabular}{cccc}
\hline Species & Genome Size & Acc. Number & References \\
\hline Bemisia tabaci complex sp. Asia I & $15,210 \mathrm{bp}$ & KJ778614 & {$[27]$} \\
Bemisia tabaci & $15,632 \mathrm{bp}$ & JQ906700 & {$[23]$} \\
Bemisia tabaci & $15,322 \mathrm{bp}$ & AY521259 & {$[21]$} \\
Bemisia afer & $15,300 \mathrm{bp}$ & KR819174 & {$[24]$} \\
Bemisia afer & $14,968 \mathrm{bp}$ & KF734668 & {$[22]$} \\
Tetraleurodes acaciae & $15,080 \mathrm{bp}$ & AY521262 & {$[21]$} \\
Neomaskellia andropogonis & $14,496 \mathrm{bp}$ & AY572539 & {$[21]$} \\
Aleurochiton aceris & $15,388 \mathrm{bp}$ & AY572538 & {$[21]$} \\
Aleurodicus dugesii & $15,723 \mathrm{bp}$ & AY521251 & {$[21]$} \\
Trialeurodes vaporariorum & $18,414 \mathrm{bp}$ & AY521265 & {$[21]$} \\
Drosophila melanogaster & $19,517 \mathrm{bp}$ & DMU37541 & {$[42]$} \\
\hline
\end{tabular}




\subsection{Phylogenetic Analyses}

We indicated the relationship of the camellia spiny whitefly to seven other whiteflies (three strains of Bemisia tabaci and two strains of Bemisi aafer) with concatenated mt gene sequences of: (1) nucleotide sequences of 12 protein-coding genes and two rRNA genes (atp8 excluded); (2) amino acid sequence of 12 protein-coding genes (atp8 excluded). Atp 8 and tRNA genes were excluded because they are too short to align among $12 \mathrm{mt}$ genomes. All sequences of genes were aligned individually by ClustalW in MEGA 5 [49]. Nucleotide sequences of PCGs were aligned at the amino acid level, then back-translated into nucleotide sequences. Poorly aligned sites of each alignment have been removed using the Gblocks server (available online: http://molevol.cmima.csic.es/castresana/Gblocks_server.html) [50] with all options for a stringent selection were chosen. We using DAMBE 5.3.9 to test substitution saturations of aligned nucleotide sequences [51]. Whole PCG nucleotide sequences would enter the next step if $I_{\mathrm{ss}}$ was significantly lower than $I_{\text {ss.c }}(p<0.05)$. Ten protein-coding genes passed this test, and the third codon positions of nad4L and nad6 were excluded then the remainder passed the test. Subsequently, alignments of individual genes were concatenated. According to the Akaike Information Criterion, the best fit models for nucleotide sequence alignment was determined by jModelTest 2.1.4 [52,53], and amino acid sequence alignment by ProtTest 3.2 [54]. Then, GTR+I+G model and MtArt+I+G model were chosen. The two concatenated alignments were used in maximum likelihood (ML) and Bayesian inference (BI) with PhyML3.0 (available online: http:/ /www.atgc-montpellier.fr/phyml/) [55] and MrBayes v3.2.2 [56,57]. ML analyses were performed with substitution models "GTR" or "MtArt", type of tree improvement "SPR \& NNI", and the shape parameters and the propotions of invariable sites were estimated by jModelTest 2.1.4 and ProtTest 3.2. For BI analyses, four independent Markov chains were simultaneously run for 2,000,000 generations with a heating scheme (temp $=0.2$ ); Trees were sampled every 100 generations (sample-freq $=100$ ) and the first $25 \%$ were discarded as burn-in. Stationarity was considered to be reached when the average standard deviation of split frequencies was below 0.01 [58].

\section{Conclusions}

We sequenced the complete $\mathrm{mt}$ genome of camellia spiny whitefly, Aleurocanthus camelliae. This $\mathrm{mt}$ genome shares many features with those reported insect mt genomes. It is a typical closed-circular and double stranded DNA molecule in size of $15,188 \mathrm{bp}$. Distinctively, it has unique gene arrangement and trnI could not be identified. The mt genome encodes 13 protein-coding genes, 2 ribosomal and 22 transfer RNA genes, but no trnI. Gene absence is a common phenomenon of whitefly $\mathrm{mt}$ genomes. Using ARWEN and homologous sequence alignment, we have identified five tRNA genes and revised genome annotations of A. dugesii, N. andropogonis and T. acaciae in this study. The gene order of camellia spiny whitefly is similar to that of T. acaciae. Phylogenetic relationships among 11 whiteflies and D. melanogaster based on $\mathrm{mt}$ genome sequence are concordant with that inferred from $\mathrm{mt}$ gene order. This infers that gene rearrangement plays an important role in the $\mathrm{mt}$ genome evolved from whiteflies.

Supplementary Materials: Supplementary materials can be found at www.mdpi.com/1422-0067/17/11/1843/s1. Acknowledgments: This work was supported by General Fundamental and Advanced Research Project of Chongqing (cstc2015jcyjA80038), National Tea Industry Technology System Research Project of China (CARS-23), Agricultural Development Fund of Chongqing Academy of Agricultural Sciences (NKY-2016AC014) and Natural Science Foundation Project of Yongchuan Science \& Technology Commission (Ycstc, 2015nc1005).

Author Contributions: Shi-Chun Chen, Xiao-Qing Wang, Jin-Jun Wang and Ping Peng conceived and designed the experiments; Shi-Chun Chen, Xiao-Qing Wang, Xiang Hu and Pin-Wu Li performed the experiments and analyzed the data; Ping Peng contributed reagents/materials/analysis tools; Shi-Chun Chen wrote the paper.

Conflicts of Interest: The authors declare no conflict of interest. 


\section{References}

1. Fu, J.Y.; Han, B.Y.; Xiao, Q. Mitochondrial COI and 16sRNA evidence for a single species hypothesis of E. vitis, J. formosana and E. onukii in East Asia. PLoS ONE 2014, 9, e115259. [CrossRef] [PubMed]

2. Kanmiya, K.; Ueda, S.; Kasai, A.; Yamashita, K.; Sato, Y.; Yoshiyasu, Y. Proposal of new specific status for tea-infesting populations of the nominal citrus spiny whitefly Aleurocanthus spiniferus (Homoptera: Aleyrodidae). Zootaxa 2011, 2797, 25-44.

3. Cameron, S.L. Insect mitochondrial genomics: Implications for evolution and phylogeny. Annu. Rev. Entomol. 2014, 59, 95-117. [CrossRef] [PubMed]

4. Chen, S.C.; Wei, D.D.; Shao, R.; Dou, W.; Wang, J.J. The complete mitochondrial genome of the booklouse, Liposcelis decolor: Insights into gene arrangement and genome organization within the genus Liposcelis. PLoS ONE 2014, 9, e91902. [CrossRef] [PubMed]

5. Shao, R.; Barker, S.C.; Li, H.; Song, S.; Poudel, S.; Su, Y. Fragmented mitochondrial genomes in two suborders of parasitic lice of eutherian mammals (Anoplura and Rhynchophthirina, Insecta). Sci. Rep. 2015, 5. [CrossRef] [PubMed]

6. Shao, R.; Zhu, X.Q.; Barker, S.C.; Herd, K. Evolution of extensively fragmented mitochondrial genomes in the lice of humans. Genome Biol. Evol. 2012, 4, 1088-1101. [CrossRef] [PubMed]

7. Cameron, S.L.; Yoshizawa, K.; Mizukoshi, A.; Whiting, M.F.; Johnson, K.P. Mitochondrial genome deletions and minicircles are common in lice (Insecta: Phthiraptera). BMC Genom. 2011, 12. [CrossRef] [PubMed]

8. Chen, S.C.; Wei, D.D.; Shao, R.; Shi, J.X.; Dou, W.; Wang, J.J. Evolution of multipartite mitochondrial genomes in the booklice of the genus Liposcelis (Psocoptera). BMC Genom. 2014, 15. [CrossRef] [PubMed]

9. Wei, D.D.; Yuan, M.L.; Wang, B.J.; Zhou, A.W.; Dou, W.; Wang, J.J. Population genetics of two asexually and sexually reproducing psocids species inferred by the analysis of mitochondrial and nuclear DNA sequences. PLOS ONE 2012, 7, e33883. [CrossRef] [PubMed]

10. Zhang, G.H.; Yuan, Z.J.; Zhang, C.X.; Yin, K.S.; Tang, M.J.; Guo, H.W.; Fu, J.Y.; Xiao, Q. Detecting deep divergence in seventeen populations of tea geometrid (Ectropis obliqua Prout) in China by COI mtDNA and cross-breeding. PLoS ONE 2014, 9, e99373. [CrossRef] [PubMed]

11. Gissi, C.; Iannelli, F.; Pesole, G. Evolution of the mitochondrial genome of Metazoa as exemplified by comparison of congeneric species. Heredity 2008, 101, 301-320. [CrossRef] [PubMed]

12. Simon, C.; Buckley, T.R.; Frati, F.; Stewart, J.B.; Beckenbach, A.T. Incorporating molecular evolution into phylogenetic analysis, and a new compilation of conserved polymerase chain reaction primers for animal mitochondrial DNA. Annu. Rev. Ecol. Evol. Syst. 2006, 37, 545-579. [CrossRef]

13. Bernt, M.; Braband, A.; Schierwater, B.; Stadler, P.F. Genetic aspects of mitochondrial genome evolution. Mol. Phylogenet. Evol. 2013, 69, 328-338. [CrossRef] [PubMed]

14. Boore, J.L. Animal mitochondrial genomes. Nucleic Acids Res. 1999, 27, 1767-1780. [CrossRef] [PubMed]

15. Burger, G.; Gray, M.W.; Lang, B.F. Mitochondrial genomes: Anything goes. Trends Genet. 2003, 19, 709-716. [CrossRef] [PubMed]

16. Simon, S.; Hadrys, H. A comparative analysis of complete mitochondrial genomes among Hexapoda. Mol. Phylogenet. Evol. 2013, 69, 393-403. [CrossRef] [PubMed]

17. Wolstenholme, D.R. Animal mitochondrial DNA: structure and evolution. Int. Rev. Cytol. 1992, 141, $173-216$. [PubMed]

18. Dickey, A.M.; Kumar, V.; Morgan, J.K.; Jara-Cavieres, A.; Shatters, R.G., Jr.; McKenzie, C.L.; Osborne, L.S. A novel mitochondrial genome architecture in thrips (Insecta: Thysanoptera): Extreme size asymmetry among chromosomes and possible recent control region duplication. BMC Genom. 2015, 16. [CrossRef] [PubMed]

19. Wei, D.D.; Shao, R.; Yuan, M.L.; Dou, W.; Barker, S.C.; Wang, J.J. The multipartite mitochondrial genome of Liposcelis bostrychophila: Insights into the evolution of mitochondrial genomes in bilateral animals. PLoS ONE 2012, 7, e33973. [CrossRef] [PubMed]

20. Martin, J.H.; Mifsud, D.; Rapisarda, C. The whiteflies (Hemiptera: Aleyrodidae) of Europe and the Mediterranean Basin. Bull. Entomol. Res. 2000, 90, 407-448. [CrossRef] [PubMed]

21. Thao, M.L.; Baumann, L.; Baumann, P. Organization of the mitochondrial genomes of whiteflies, aphids, and psyllids (Hemiptera, Sternorrhyncha). BMC Evol. Biol. 2004, 4. [CrossRef] [PubMed] 
22. Wang, H.L.; Xiao, N.; Yang, J.; Wang, X.W.; Colvin, J.; Liu, S.S. The complete mitochondrial genome of Bemisia afer (Hemiptera: Aleyrodidae). Mitochondr. DNA A 2016, 27, 98-99. [CrossRef] [PubMed]

23. Wang, H.L.; Yang, J.; Boykin, L.M.; Zhao, Q.Y.; Li, Q.; Wang, X.W.; Liu, S.S. The characteristics and expression profiles of the mitochondrial genome for the Mediterranean species of the Bemisia tabaci complex. BMC Genom. 2013, 14. [CrossRef] [PubMed]

24. Wang, H.L.; Zhang, Z.; Bing, X.L.; Liu, Y.Q.; Liu, S.S.; Wang, X.W. A complete mitochondrial DNA genome derived from a Chinese population of the Bemisia afer species complex (Hemiptera: Aleyrodidae). Mitochondr. DNA A 2015, 27, 3500-35011. [CrossRef] [PubMed]

25. Boore, J.L. Complete mitochondrial genome sequence of the polychaete annelid Platynereis dumerilii. Mol. Biol. Evol. 2001, 18, 1413-1416. [CrossRef] [PubMed]

26. Ojala, D.; Montoya, J.; Attardi, G. tRNA punctuation model of RNA processing in human mitochondria. Nature 1981, 290, 470-474. [CrossRef] [PubMed]

27. Tay, W.T.; Elfekih, S.; Court, L.; Gordon, K.H.; de Barro, P.J. Complete mitochondrial DNA genome of Bemisia tabaci cryptic pest species complex Asia I (Hemiptera: Aleyrodidae). Mitochondr. DNA 2016, 27, 972-973. [CrossRef] [PubMed]

28. Lavrov, D.V.; Brown, W.M.; Boore, J.L. A novel type of RNA editing occurs in the mitochondrial tRNAs of the centipede Lithobius forficatus. Proc. Natl. Acad. Sci. USA 2000, 97, 13738-13742. [CrossRef] [PubMed]

29. Helfenbein, K.G.; Fourcade, H.M.; Vanjani, R.G.; Boore, J.L. The mitochondrial genome of Paraspadella gotoi is highly reduced and reveals that chaetognaths are a sister group to protostomes. Proc. Natl. Acad. Sci. USA 2004, 101, 10639-10643. [CrossRef] [PubMed]

30. Kayal, E.; Lavrov, D.V. The mitochondrial genome of Hydra oligactis (Cnidaria, Hydrozoa) sheds new light on animal mtDNA evolution and cnidarian phylogeny. Gene 2008, 410, 177-186. [CrossRef] [PubMed]

31. Duchene, A.M.; Pujol, C.; Marechal-Drouard, L. Import of tRNAs and aminoacyl-tRNA synthetases into mitochondria. Curr. Genet. 2009, 55, 1-18. [CrossRef] [PubMed]

32. Hwang, D.S.; Suga, K.; Sakakura, Y.; Park, H.G.; Hagiwara, A.; Rhee, J.S.; Lee, J.S. Complete mitochondrial genome of the monogonont rotifer, Brachionus koreanus (Rotifera, Brachionidae). Mitochondr. DNA 2014, 25, 29-30. [CrossRef] [PubMed]

33. Suga, K.; Welch, D.B.M.; Tanaka, Y.; Sakakura, Y.; Hagiwarak, A. Two circular chromosomes of unequal copy number make up the mitochondrial genome of the rotifer Brachionus plicatilis. Mol. Biol. Evol. 2008, 25, 1129-1137. [CrossRef] [PubMed]

34. Jeyaprakash, A.; Hoy, M.A. The mitochondrial genome of the predatory mite Metaseiulus occidentalis (Arthropoda:Chelicerata:Acari:Phytoseiidae) is unexpectedly large and contains several novel features. Gene 2007, 391, 264-274. [CrossRef] [PubMed]

35. Dermauw, W.; Vanholme, B.; Tirry, L.; van Leeuwen, T. Mitochondrial genome analysis of the predatory mite Phytoseiulus persimilis and a revisit of the Metaseiulus occidentalis mitochondrial genome. Genome 2010, 53, 285-301. [PubMed]

36. Stewart, J.B.; Beckenbach, A.T. Characterization of mature mitochondrial transcripts in Drosophila, and the implications for the tRNA punctuation model in arthropods. Gene 2009, 445, 49-57. [CrossRef] [PubMed]

37. Boore, J.L. The duplication/random loss model for gene rearrangement exemplified by mitochondrial genomes of deuterostome animals. Comp. Genom. 2000, 1, 133-147.

38. Mao, M.; Gibson, T.; Dowton, M. Evolutionary dynamics of the mitochondrial genome in the evaniomorpha (hymenoptera) - A group with an intermediate rate of gene rearrangement. Genome Biol. Evol. 2014, 6, 1862-1874. [CrossRef] [PubMed]

39. Mao, M.; Dowton, M. Complete mitochondrial genomes of Ceratobaeus sp. and Idris sp. (Hymenoptera: Scelionidae): Shared gene rearrangements as potential phylogenetic markers at the tribal level. Mol. Biol. Rep. 2014, 41, 6419-6427. [CrossRef] [PubMed]

40. Dowton, M.; Campbell, N.J. Intramitochondrial recombination-Is it why some mitochondrial genes sleep around? Trends Ecol. Evol. 2001, 16, 269-271. [CrossRef]

41. Kurabayashi, A.; Sumida, M.; Yonekawa, H.; Glaw, F.; Vences, M.; Hasegawa, M. Phylogeny, recombination, and mechanisms of stepwise mitochondrial genome reorganization in mantellid frogs from Madagascar. Mol. Biol. Evol. 2008, 25, 874-891. [CrossRef] [PubMed]

42. Lewis, D.L.; Farr, C.L.; Farquhar, A.L.; Kaguni, L.S. Sequence, organization, and evolution of the A + T region of Drosophila melanogaster mitochondrial DNA. Mol. Biol. Evol. 1994, 11, 523-538. [PubMed] 
43. Dowton, M.; Castro, L.R.; Austin, A.D. Mitochondrial gene rearrangements as phylogenetic characters in the invertebrates: The examination of genome "morphology". Invertebr. Syst. 2002, 16, 345-356. [CrossRef]

44. Uesugi, K.; Sato, Y.; Han, B.Y.; Huang, Z.-D.; Yara, K.; Furuhashi, K. Molecular evidence for multiple phylogenetic groups within two species of invasive spiny whiteflies and their parasitoid wasp. Bull. Entomol. Res. 2016, 106, 328-340. [CrossRef] [PubMed]

45. Frohlich, D.R.; Torres-Jerez, I.; Bedford, I.D.; Markham, P.G.; Brown, J.K. A phylogeographical analysis of the Bemisia tabaci species complex based on mitochondrial DNA markers. Mol. Ecol. 1999, 8, 1683-1691. [CrossRef] [PubMed]

46. Simon, C.; Frati, F.; Beckenbach, A.; Crespi, B.; Liu, H.; Flook, P. Evolution, weighting, and phylogenetic utility of mitochondrial gene-sequences and a compilation of conserved polymerase chain-reaction primers. Ann. Entomol. Soc. Am. 1994, 87, 651-701. [CrossRef]

47. Laslett, D.; Canback, B. ARWEN: A program to detect tRNA genes in metazoan mitochondrial nucleotide sequences. Bioinformatics 2008, 24, 172-175. [CrossRef] [PubMed]

48. Lowe, T.M.; Eddy, S.R. tRNAscan-SE: A program for improved detection of transfer RNA genes in genomic sequence. Nucleic Acids Res. 1997, 25, 955-964. [CrossRef] [PubMed]

49. Tamura, K.; Peterson, D.; Peterson, N.; Stecher, G.; Nei, M.; Kumar, S. MEGA5: Molecular evolutionary genetics analysis using maximum likelihood, evolutionary distance, and maximum parsimony methods. Mol. Biol. Evol. 2011, 28, 2731-2739. [CrossRef] [PubMed]

50. Castresana, J. Selection of conserved blocks from multiple alignments for their use in phylogenetic analysis. Mol. Biol. Evol. 2000, 17, 540-552. [CrossRef] [PubMed]

51. Xia, X.; Lemey, P. Assessing substitution saturation with DAMBE. In Phylogenetic Handbook: A Practical Approach to Phylogenetic Analysis and Hypothesis Testing, 2nd ed.; Cambridge University Press: Cambridge, UK, 2009; pp. 615-630.

52. Darriba, D.; Taboada, G.L.; Doallo, R.; Posada, D. jModelTest 2: More models, new heuristics and parallel computing. Nat. Methods 2012, 9. [CrossRef] [PubMed]

53. Posada, D. jModelTest: Phylogenetic model averaging. Mol. Biol. Evol. 2008, 25, 1253-1256. [CrossRef] [PubMed]

54. Darriba, D.; Taboada, G.L.; Doallo, R.; Posada, D. ProtTest 3: Fast selection of best-fit models of protein evolution. Bioinformatics 2011, 27, 1164-1165. [CrossRef] [PubMed]

55. Guindon, S.; Gascuel, O. A simple, fast, and accurate algorithm to estimate large phylogenies by maximum likelihood. Syst. Biol. 2003, 52, 696-704. [CrossRef] [PubMed]

56. Ronquist, F.; Huelsenbeck, J.P. MrBayes 3: Bayesian phylogenetic inference under mixed models. Bioinformatics 2003, 19, 1572-1574. [CrossRef] [PubMed]

57. Ronquist, F.; Teslenko, M.; van der Mark, P.; Ayres, D.L.; Darling, A.; Hohna, S.; Larget, B.; Liu, L.; Suchard, M.A.; Huelsenbeck, J.P. MrBayes 3.2: Efficient Bayesian phylogenetic inference and model choice across a large model space. Syst. Biol. 2012, 61, 539-542. [CrossRef] [PubMed]

58. Huelsenbeck, J.P.; Ronquist, F.; Nielsen, R.; Bollback, J.P. Bayesian inference of phylogeny and its impact on evolutionary biology. Science 2001, 294, 2310-2314. [CrossRef] [PubMed]

(C) 2016 by the authors; licensee MDPI, Basel, Switzerland. This article is an open access article distributed under the terms and conditions of the Creative Commons Attribution (CC-BY) license (http:/ / creativecommons.org/licenses/by/4.0/). 